\title{
Semantic/Phonological Error Characteristics and Reading Fluency for School-Aged Children with Language Learning Disabilities in 3rd to 4th Grades
}

\author{
Si-Hwa Chae ${ }^{a}$, Mibae Kim ${ }^{\mathrm{b}}$ \\ ${ }^{a}$ Graduate Program in Speech and Hearing Therapy, Catholic University of Pusan, Busan, Korea \\ ${ }^{b}$ Daon Language Learning Center, Seongnam, Korea
}

Correspondence: Mibae Kim, PhD

Daon Language Learning Center, 322

Wiryegwangjang-ro, Sujeong-gu, Seongnam 13640, Korea

Tel: +82-31-756-5559

E-mail: maria050401@hanmail.net

Received: April 2, 2019

Revised: May 14, 2019

Accepted: June 3, 2019

This work is based on the master's thesis of the first author
Objectives: The time period between grades 3 and 4 is the period when reading fluency (RF) is achieved. RF should be achieved before reaching the final goal of reading, and reading comprehension. Therefore we investigated the RF of children with language learning disabilities (LLD) with language problems. And investigated the characteristics of reading error in detail. Methods: Seventeen children LLD in the 3rd and 4th grades of elementary school, 17 typically developing (TD) children who matched in grade level and were from the same area, for a total of 34 children. RF was examined through reading two stories, and the number of syllables correctly read per minute, accuracy, and speed were examined. The errors were classified into semantic and phonological errors, and the number of errors and error types were examined. Results: It was found that the number of syllables correctly read per minute, accuracy, and speed of reading by children with LLD was significantly lower than that of TD children. Also, the total of both semantic and phonological errors was significantly higher. Substitution was the most frequent type of semantic error. The most common types of semantic errors exhibited by TD children were self-correction, repetition, omission, and addition respectively; whereas the errors exhibited by children with LLD appeared in the order of repetition, omission, addition, and self-correction. Phonological errors were common in the order of repetition, substitution, and self-correction. For TD children addition was more common than omission, and for children with LLD omission was more common than addition. Conclusion: In this study, we examined the RF characteristics of 3-4 graders with LLD and identified semantic and phonological error characteristics. Children with LLD who have difficulties with language and reading have difficulty reading text automatically. In particular, the characteristic of semantic and phonological errors was prominent. Therefore, it is necessary to consider RF in the course of assessment and intervention.

Keywords: Language-learning disabilities, Reading fluency, Accuracy, Speed, Semantic/ phonological error, Error type
읽기란 글로부터 의미를 얻는 다양한 과정으로 사람이 살아가 는 데 필요한 의사소통 기술이며 복잡하고 다양한 지식과 기술을 요구한다. 읽기의 단순 관점(simple view of reading)에서 읽기이해 는 해독(decoding)과 언어이해 과정 모두를 뜻하며 둘 중 하나라도 문제가 생겼을 경우 읽기의 궁극적 목표인 읽기이해에 어려움이 생 긴다(Gough \& Tunmer, 1986). 읽기는 음운, 의미, 구문, 화용능력
등 언어능력과 연결되며 학령전기에 언어에 결함을 보인 아동은 학 령기에 언어결함이 동반된 읽기에 어려움을 보인다(Rescorla, 2005; Scarborough \& Dobrich, 1990; Storch \& Whitehurst, 2002). 학령 기의 읽기와 언어는 독립적이 아닌 상호적인 관계로 발달하므로 학 령기 아동들의 언어발달 지체는 읽기의 어려움을 야기한다(Catts, Fey, Tomblin, \& Zhang, 2002). 따라서 언어결함을 동반한 아동의 
언어특성을 고려한 읽기 특성의 파악이 필요하다.

Silliman, Butler와 Wallach (2001)는 언어와학습 모두에 어려움 을 가진 아동을 언어학습장애(language learning disability, LLD) 라고 하였다. 또한 취약한 언어능력으로 인하여 읽기에 어려움을 보이는 아동들을 언어학습장애로 언급하였으며 읽기장애(reading disability)와 동일시하였다(Kamhi \& Catts, 2012). 언어학습장애 아동은 구어 기초에 근본적인 약점이 있으며 언어발달이 지연된 과 거력이 있다(Paul \& Norbury, 2012). 이는 적절한 어휘를 선택하고 문장을 규칙에 따라 배열하는 능력 등 언어능력에 어려움을 보인 다(German \& Simon, 1991; MacLachlan \& Chapman, 1988). 또한 언어적 결함은 읽기의 어려움으로 나타나는데, 자신이 읽은 글의 내용을 이해하는 데 어려움을 보이거나(Bishop \& Adams, 1992), 읽기학습에 중요한 음운이해에 종종 장애를 보여 해독 및 읽기유 창성에 중요한 영향을 미친다(Liberman \& Liberman, 1990; Pennington \& Bishop, 2009). 이러한 해독, 읽기유창성의 어려움은 읽 기의 최종목표인 읽기이해로 전환되는 데 어려움을 보인다. 또한 Chall (1983)의 읽기 발달단계를 보면 초등 저학년 시기에는 읽기를 배우는 단계(learn to read)로 자소-음소 대응 단어를 읽는 해독 기 술이 발달하고, 초등 중학년은 학습을 위해 읽는 단계(read to learn) 로 자동화된 해독 능력이 발달하여 정확률이 높아지고 유창하게 읽을 수 있다. 따라서 Chall (1983)의 읽기 발달단계에서도 읽기유 창성은 글자 해독과 의미적인 접근을 통하여 읽기이해와 연결해 주는 다리의 역할을 하는 주요한 기술이라는 것을 확인할 수 있다 (Fuchs, Fuchs, Hosp, \& Jenkins, 2001).

읽기유창성(reading fluency)이란 글을 빠르고 노력 없이 자동적 으로 읽는 능력으로 해독의 정확률 및 자동화, 강세, 세기, 높이, 띄 어 읽기와 같은 운율의 적절성을 포함한다(Kuhn \& Stahl, 2003; Logan, 1997). 이는 해독, 이름대기 속도, 철자 인식, 의미, 구문, 형 태 등의 언어적 지식을 통합적으로 보여주는 능력이며(Wolf, 2007), Silberglitt와 Hintze (2005)는 음운인식, 해독, 읽기이해와 같은 읽 기 하위영역과 상관관계가 있다고 한다. 또한 단어 및 텍스트글을 자동적으로 읽기 위해서는 언어적 처리 과정인 해독과 언어이해가 중요하다(Bashir \& Hook, 2009). 그러나 최근 여러 연구들을 통해 읽기이해를 해독과 언어이해로만 설명하는 것은 제한적이라고 하며 읽기유창성에 관심을 갖기 시작하였다(Kim, Park, \& Kim, 2010; Quinn, Wagner, Petscher, \& Lopez, 2015; Torgesen \& Hudson, 2006).

Kim과 Pae (2012)의 연구에서는 읽기부진 아동은 일반아동보 다 읽기유창성 수행력이 유의미하게 낮았고 Kim과 Park (2010)의 연구에서는 초등 2, 4학년 읽기장애 학생은 일반학생보다 읽기유
창성이 낮았으며 읽기 오류 빈도 또한 높게 나타났다. Pae 등(2017) 에 의하면 초등 저학년, 중학년, 고학년 발달성 난독 아동 모두 10 초 당 정확하게 읽은 음절수 즉, 읽기유창성이 일반아동보다 어려움 을 보였다. 또한 Woo와 $\operatorname{Kim}$ (2010)에 의하면 초등 3-6학년 읽기장 애 학생과 일반학생의 읽기유창성 능력을 비교한 결과, 읽기장애 학생의 읽기유창성 능력이 더 낮았다. 따라서 선행연구에서 살펴본 것과 같이 읽기에 어려움을 보이는 아동은 자동적으로 글을 읽는 읽기유창성에서 결함을 보였다. Bashir과 Hook (2009)은 초등 3-4 학년 시기는 읽기를 배우는 단계에서 학습을 위해 읽는 단계로의 전환이 이루어지며 두 측면을 연결하는 것이 읽기유창성이라 하였 다. 따라서 이러한 읽기유창성의 어려움은 어느 변인의 결함으로 인하여 나타나는지 자세히 살펴보고 그 변인에 대하여 지원해 주 어야한다.

읽기유창성은 정확도, 속도, 운율의 하위요소로 구성되어 있으 며(Hudson, Lane, \& Pullen, 2005) 읽기 정확률×읽기 속도로 정 확률과 속도가 모두 중요하다. 그러므로 읽기 정확률이 읽기유창 성에서 선행되어야 하는 필수요소 중 하나이다. 읽기 정확률은 글 자를 읽어내는 능력으로 인쇄되어진 글자를 소리로 전환하는 것을 말한다. 그러나 정확률이 향상되더라도 읽기 속도에만 어려움을 보 이는 아동이 $8 \%$ 존재한다는 선행연구가 있다(Morris et al., 1998). Jenkins, Fuchs, Van Den Broek, Espin과 Deno (2003)에 의하면 읽 기유창성의 결함의 유형이 다를 수 있으며 읽기유창성의 문제를 읽 기 정확률과 읽기 속도의 두 유형으로 나눌 수 있다고 한다. 따라서 읽기유창성을 정확률과 속도로 나누어 평가하고 지원하는 것이 어 떤 변인이 읽기유창성에 영향을 미치는지 알 수 있어 평가 및 교육 에 유용할 것이다. 국내에서 읽기유창성을 평가하기 위해 사용되는 평가도구들은 기초학습기능 수행평가체계(Basic Academic Skills Assessment, BASA; Kim, 2008), 한국어 읽기검사(KOrean Language based Reading Assessment, KOLRA; Pae, Kim, Yoon, \& Jang, 2015), 읽기 성취 및 읽기 인지처리능력 검사(Test of Reading Achievement and Reading Cognitive Processes Ability, RA-RCP; $\mathrm{Kim}, \mathrm{Kim}, \mathrm{Hwang}$, \& Yoo, 2014)가 있다. 읽기유창성을 평가하는 방법은 1 분 또는 10 초당 얼마나 정확하게 읽는지를 살펴보고 있다. 읽기유창성을 평가하는 국내의 선행연구들을 살펴보면 Kim (2017) 의 연구에서 초등 3-4학년 아동을 대상으로 읽기유창성을 속도, 정 확률, 속도와 정확률을 모두 포함한 전체 읽기유창성으로 나누어 살펴보았고, Lee와 $\operatorname{Kim}$ (2012)의 연구에서는 초등 2-3학년 $\mathrm{ADHD}$ 아동을 대상으로 읽기유창성을 속도와 정확률로 나누어 살펴보았 다. Kim, Pae와 Kim (2012)의 연구에서는 초등 3-4학년 ADHD 아 동을 대상으로 읽은 속도, 정확하게 읽은 음절수, 정확하게 읽은 분 
당 음절수로 읽기유창성을 확인하였다. 따라서 국내 선행연구에서 도 살펴보았듯이 읽기유창성을 살펴보기 위해서는 읽기 정확률과 읽기 속도가 모두 중요한 변인이므로 두 가지를 나누어 자세하게 살펴본다면 아동의 읽기유창성 특성을 세부적으로 알 수 있을 것 이다.

읽기유창성의 질적 분석인 읽기 오류 분석은 아동의 읽기유창성 능력을 자세히 평가하는 데 유용하다. 읽기 오류는 독자가 집중하 지 않아 실수로 나타나는 것이 아닌 해독과 언어적 지식 통합의 결 함에 의해서 나타나는 것이다(Wolf, 2007). 읽기 오류 중 자기수정, 반복, 생략, 대치의 오류를 분석하는 것이 아동의 해독능력 발달 과 정을 확인할 수 있다고 한다(McKenna \& Picard, 2006). 이러한 읽 기 오류 분석은 아동의 읽기 특성을 자세하게 알 수 있으나 국내 검 사도구에는 질적 분석이 없으므로 오류를 어떤 유형으로 분석하 는지 등의 지표가 필요할 것이다. 대부분의 선행연구에서는 읽기유 창성을 읽기 오류율, 읽기 오류 빈도, 읽기 오류 유형으로 분석하여 확인하였다(Kim et al., 2012; Lee \& Kim, 2012; Shim \& Jung, 2012). 읽기 오류 유형을 선정하는 것은 연구자들마다 상이하였는데 Kim 과 Park (2010)에 의하면 텍스트 수준에서의 오류 유형(문맥상 의 미가 통하는지 유무)과 어절 수준(자기교정, 생략, 첨가, 반복, 대치) 에서의 오류 유형으로 분류하였고, Pae (2004)에 의하면 유해오류 (삽입, 대치, 반전, 생략 오류)와 무해오류(수정, 반복 오류)로 분류, Shim과 Jung (2012)에 의하면 삽입, 반복, 대치, 수정, 생략, 음운규 칙 미적용을 내용어와 기능어로 분류하였다. 대부분의 선행연구에 서는 공통적으로 읽기 오류 유형을 생략, 첨가, 대치, 반복, 수정으 로 나누어 살펴보고 있다. 읽기유창성은 언어적 요소를 포함하며 어휘력이 읽기유창성 능력을 예측한다는 연구와(Kim \& Hwang, 2008; Vellutino, Tunmer, Jaccard, \& Chen, 2007) 음운처리 능력이 읽기와 상관이 높다는 연구가 보고되었다(Bradley \& Bryant, 1983; Goswami \& Bryant, 1990). 또한 Jenkins 등(2003)의 연구에서는 글을 유창하게 읽기 위해서 의미와 음운 두 경로 모두가 필수적 요 인이라 한다. 따라서 읽기유창성의 결함이 언어 요소 중 의미영역 의 어려움인지 음운영역의 어려움인지 확인해야 한다.

읽기유창성에 도달하기 위해서는 해독의 자동성이 중요하며 이 는 음운해독 과정에 대한 이중 경로모형(Dual-Route Model)으로 연결하여 설명할 수 있다. 의미경로(lexical route)를 통한 글 읽기는 의미경로로 인쇄물에서 시각적으로 인지한 상징을 심성어휘집의 어휘 정보를 통하여 어떤 의미인지 찾아낸 후 소리를 내어 읽는다 (Castles, Bates, Coltheart, Luciano, \& Martin, 2006). 따라서 의미 경로를 사용하면 철자의 구성이 많고 음절이 복잡한 '크리스마스' 단어를 빠르고 정확하게 읽을 수 있다. 그러나 의미오류가 나타날
때는 ‘크리스마스’를 ‘크레파스’로 글자를 다르게 읽는 오류가 나타 날 것이다.

음운오류는 비친숙한 낱말 또는 무의미음절은 음운부호로 해독 한 다음 심성어휘집의 어휘와음운부호를 연결하여 산출하게 되는 음운경로(phonological route)를 통한 읽기 과정에서 생기는 오류 이다. 이는 처음 보는 낱말이나 비단어 '커부마라시'를 '카부마리시' 로 글자를 틀리게 읽는 오류가 나타날 것이다. 따라서 아동의 읽기 오류특성을 살펴볼 때 읽기 오류율, 읽기 오류 빈도, 읽기 오류 유형 으로만 확인하는 것이 아니라 이러한 오류가 읽기유창성에서 필요 한 언어능력인 의미와 음운에 기반하여 어떻게 자동성을 습득하 는지 살펴보는 것이 읽기유창성의 결함을 더욱더 자세하게 확인할 수 있다.

초등 3-4학년은 '읽기를 배우는 단계'에서 '학습을 위해 읽는 단 계'로 전환이 이루어지는 시기이다. 이 시기는 해독에서 읽기이해 단계로 전환되는 시기로 읽기유창성이 완성된다. 읽기유창성은 해 독과 의미적인 접근을 통하여 읽기의 최종목표인 읽기이해와 연결 해주는 다리의 역할을 하는 주요한 능력이다. 그러나 읽기유창성이 중요한 시기인 초등 3-4학년을 대상으로 한 읽기 연구는 찾아보기 어려웠다. 또한 읽기유창성은 읽기 정확률 $\times$ 읽기 속도로 정확률과 속도 모두가 중요한 변인이다. 그러나 대부분의 선행연구에서는 읽 기유창성을 분당 정확하게 읽은 음절수, 읽기 정확률, 읽기 속도로 나누어 각각 세부적으로 확인하는 연구가 부족하였다. 또한 읽기 오류율, 읽기 오류 빈도, 읽기 오류 유형으로만 살펴보는 연구가 대 부분이었고 읽기유창성에서 필요한 언어 특성을 고려한 의미 또는 음운으로 나누어 살펴보는 연구가 부족한 모습이었다. 따라서 본 연구에서는 읽기유창성을 분당 정확하게 읽은 음절수, 읽기 정확 률, 읽기 속도로 세부적인 요인으로 나누어 살펴보고 오류를 의미 와음운으로 나누어 살펴보았다. 이는 학습을 위해 읽는 단계인 초 등 중학년의 읽기유창성과 오류패턴을 확인하여 실제 임상현장에 서 평가와 중재 시에 기초선 선정 시에 도움이 될 것이다.

연구 문제는 다음과 같다.

1) 초등 3-4학년 아동의 집단(일반, 언어학습장애)은 읽기유창성 (분당 정확하게 읽은 음절수, 읽기 정확률, 읽기 속도)에 차이 가 있는가?

2) 초등 3-4학년 아동의 집단(일반, 언어학습장애)은 전체 오류 수, 의미/음운 오류수에 차이가 있는가?

3) 초등 3-4학년 일반아동과 언어학습장애 아동의 전체 오류 유 형 비율, 의미/음운 오류 유형 비율은 어떠한가? 


\section{연구방법}

\section{연구대상}

본 연구의 대상은 부산시 소재의 초등학교에 재학중인 초등 3-4 학년 언어학습장애 아동 17 명, 일반아동 17 명, 총 34 명을 대상으로 하였다. 일반아동은 한국 비언어성 지능검사(Korean version of Comprehensive Test of Nonverbal Intelligence-2, K-CTONI-2; Park, 2014)의 도형척도 지능지수가 80 이상으로 정상범위에 있으며, 저성 취 기준(Shaywitz, Escobar, Shaywitz, Fletcher, \& Makuch, 1992)에 따라 한국어 읽기검사(KOLRA)의 읽기지수 2의 표준점수가 91점 이상이어야 한다. 그리고 학령기 언어검사(Language Scale for School-aged Children, LSSC; Lee, Heo, \& Jang, 2015)의 전체 언어지 수가 95 이상으로 평균 이상이며, 부모나 교사에 의해 신체, 정서, 청 력에 문제가 없다고보고된 아동으로 선정하였다.

언어학습장애 아동은 한국 비언어성 지능검사(K-CTONI-2)의 도형척도 지능지수가 80 이상으로 정상범위에 있으며, 저성취 기준 (Shaywitz et al., 1992)에 따라 한국어 읽기검사(KOLRA)의 읽기지 수 2 의 표준점수가 90 점 이하이어야 한다. 그리고 학령기 언어검사 (LSSC)의 전체 언어지수가 85점 이하에 속하는 아동으로 언어능력 이 또래 학년에 비하여 어려움이 있는 상태로 언어 중재가 필요하 다고 판단되며, 부모나 교사에 의해 신체, 정서, 청력에 문제가 없다 고 보고된 아동으로 선정하였다(Table 1).

\section{연구도구}

본 연구의 실험도구인 읽기유창성 검사는 초등학교 읽기 교과서 에서 가장 많은 비중을 차지하는 유형인 이야기글로 사용하였다. 이야기글은 선행연구 Norbury와 Bishop (2002)의 '은지의 주말 이 야기', Merritt와 Liles (1987)의 '삼형제 이야기'를 번역하여 수정한 Yun (2005)의 연구를 참고하여 수정하였다(Appendix 1). 두 개의 이야기글은 모두 4 개의 에피소드로 구성되었으며 Stein과 Glenn

Table 1. Participants' characteristics

\begin{tabular}{lllc}
\hline & LLD (N=17) & \multicolumn{1}{c}{ TD (N=17) } & $t$ \\
\hline K-CTONI-2 (IO) & $95.88(9.264)$ & $109.35(10.392)$ & $-3.989^{* * *}$ \\
KOLRA (RO2) & $63.35(22.383)$ & $108.65(8.609)$ & $-7.787^{* * *}$ \\
LSSC (LO) & $73.12(6.451)$ & $118.88(9.695)$ & $-16.204^{* * *}$ \\
\hline
\end{tabular}

Values are presented as mean (SD).

$\mathrm{LLD}=$ language learning disabilities; $\mathrm{TD}=$ children with typically developing; $\mathrm{K}$-CTO$\mathrm{NI}-2=$ Korean Comprehensive Test of Nonverbal Intelligence-2; KOLRA=Korean Language based Reading Assessment; LSSC=Language Scale for School-aged Children; $\mathrm{IQ}=$ intelligence quotient; $\mathrm{R} \mathrm{O}=$ reading quotient; $\mathrm{LO}=$ language quotient. ${ }^{* * *} p<.001$.
(1975)이 규정한 완전한 에피소드의 구성요소인 계기사건, 시도, 결 과를 포함하였다. 또한 초등 3-4학년이 읽기에 적절한 어휘와 언어 적 길이의 요소는 Lee (2014)의 연구와 Jeong (2013)의 연구를 참고 하여 수정하였다(Appendix 2).

실험도구로 사용한 읽기유창성 과제에 대하여 3 명의 학령기 아 동 언어발달의 전문가에게 내용 타당도를 의뢰하였다. 3 명의 전문 가는 언어병리학 교수이며 모두 언어병리학 박사학위 소지자이다. 3명의 전문가가 연구 절차, 연구 분석방법, 이야기 평가(난이도 및 구성), 오류 분석기준의 적합성에 대한 타당도를 Likert 5 점 척도 $(0=$ 전혀 그렇지 않다, $1=$ 그렇지 않다, $2=$ 보통이다, $3=$ 그렇다, $4=$ 매우 그렇다)로 평가하였다. 그 결과 연구 절차와 연구 분석방법에 대한 타당도는 4.7점, 이야기 평가에 대한 타당도는 4.9점, 오류 분 석기준에 대한 타당도는 4.95 점으로 높은 타당도를 검증받았다.

\section{연구절차}

검사는 시끄럽지 않은 장소에서 아동과 일대일로 진행하였다. 먼 저 선별검사(K-CTONI-2, LSSC, KOLRA)를 통해 연구대상의 조 건에 알맞은지 여부를 판단한 뒤에 본 실험인 읽기유창성 과제를 실시하였다. 실험 과제인 읽기유창성 검사는 오디오 녹음이 진행되 므로 검사자가 아동에게 검사의 모든 절차가 녹음되고 있다는 사 실을 알려준 후 검사를 진행하였다. 그리고 이야기글 2 개를 교차균 형화(cross-balancing)를 위해 순서를 조절하여 제시하면서 "선생 님은 $\mathrm{OO}($ 이)가 책을 어떻게 읽는지 알아보려고 해. 선생님이 $\mathrm{OO}($ 이) 에게 두 개의 글을 주면 평소처럼 책을 읽어주면 돼”라고 말하며 과 제를 제시하였다. 그리고 글을 읽는 도중 4초 이상 글을 읽지 않을 경우에는 그 다음 음절을 가리키며 '여기부터 다시 읽어보세요'라 고말하였다.

\section{자료분석}

연구자는 아동의 읽기 수행을 오디오 녹음을 통하여 초 단위로 측정하였으며 모든 자료는 두 개의 이야기글에서 산출되는 능력의 평균 값으로 하였다. 읽기유창성은 분당 정확하게 읽은 음절수, 읽 기 정확률, 읽기 속도로 나누어 분석하였다. 분당 정확하게 읽은 음 절수는 정확하게 읽은 음절수를 글을 읽는 데 걸린 시간(초)으로 나누어 분당(60초) 기록하였다. 읽기 정확률은 정확하게 읽은 음절 수를 기록하였으며 읽기 속도는 전체 읽기 수행에서 속도를 측정하 여 첫 음절을 읽기 시작한 후부터 마지막 음절까지 읽은 시간(초) 을 측정하였다. 읽기 오류 특성은 읽기 오류수와 읽기 오류 유형으 로 나누어 분석하였다. 전체 오류수는 이야기글을 읽으면서 나타 난 모든 오류의 전체 수를 기록하였으며 의미/음운 오류수는 의미/ 
음운 오류의 전체 수를 기록하였다. 오류 유형은 선행연구(Kim et al., 2010; Shim \& Jung, 2012)를 참고하여 어절 단위로 분석하였으 며 한 어절 안에서 나타나는 오류를 의미오류와음운오류로 각각 분 석하였다. 읽기 오류 유형은 생략, 첨가, 대치, 반복, 자기수정으로 나 누어 살펴보았다(Appendix 3). 오류 유형은 전체, 의미/음운 오류율 로 이야기글 본문을 읽으면서 나타난 전체, 의미/음운 오류의 수에 서 각 오류 유형에 따른 오류수를 비율로 기록하였다. 그러나 글을 다시 읽거나 문장과 문단을 생략하여 읽는 등 오류 유형 분석 기준 (Appendix 3)에서 벗어난 기타 오류 등은 분석에 포함하지 않았다.

본 연구에서는 읽기유창성 실험 과제의 $20 \%$ 를 임의로 선정하여 검사자 간 신뢰도를 산출하였다. 연구자를 제 1 평가자로, 임상경력 4 년 이상의 언어재활사 2 급 자격증을 소지한 1 명의 대학원생을 제 2 평가자로 선정하였다. 연구자는 제 2 평가자에게 오류 분석 기준과 채점 기준에 대하여 충분한 훈련을 진행한 후 채점 신뢰도를 측정 하였다. 읽기유창성 과제에 대한 검사자 간 채점신뢰도는 $96 \%$, 오 류 분석에 대한 채점신뢰도는 $98 \%$ 로 나타났다.

\section{통계처리}

첫째, 집단(일반, 언어학습장애)에 따른 읽기유창성(분당 정확하 게 읽은 음절수, 읽기 정확률, 읽기 속도) 차이를 알아보기 위해서 독립표본 $t$-검정(independent samples $t$-test)을 실시하였다. 둘째, 집단(일반, 언어학습장애)에 따른 전체 오류수, 의미/음운 오류수 의 차이를 알아보기 위해 독립표본 $t$-검정을 실시하였다. 통계 처리 는 SPSS Statistics version 21 프로그램을 이용하여 분석하였다.

Table 2. Reading fluency score

\begin{tabular}{lccr}
\hline & LLD (N=17) & TD (N=17) & $t$ \\
\hline RF (syllables per minute) & $103.84(34.336)$ & $259.27(36.567)$ & $-12.578^{* * *}$ \\
Accuracy & $80.57(6.474)$ & $94.88(2.533)$ & $-8.449^{* * *}$ \\
Speed & $225.76(61.415)$ & $101.28(12.960)$ & $8.166^{* * *}$ \\
\hline
\end{tabular}

Values are presented as mean (SD).

$\mathrm{LLD}=$ language learning disabilities; $T D=$ children with typically developing; $\mathrm{RF}=$ reading fluency.

asyllable of correctly reading.

${ }^{* * *} p<.001$.

Table 3. Total, semantic/phonological number of errors according to group

\begin{tabular}{lccc}
\hline & $\operatorname{LLD}(\mathrm{N}=17)$ & $\mathrm{TD}(\mathrm{N}=17)$ & $t$ \\
\hline Total number of errors & $107.59(34.335)$ & $27.75(16.827)$ & $8.395^{* * *}$ \\
Semantic number of errors & $60.53(28.717)$ & $18.00(11.983)$ & $5.609^{* * *}$ \\
Phonological number of errors & $43.35(17.403)$ & $10.56(4.912)$ & $7.459^{* * *}$
\end{tabular}

Values are presented as mean (SD).

$\mathrm{LLD}=$ language learning disabilities; $\mathrm{TD}=$ typically developing children. ${ }^{* * *} p<.001$.

\section{연구결과}

\section{초등 3-4학년 아동의 집단(일반, 언어학습장애)에 따른 읽기유창성(분당 정확하게 읽은 음절수, 읽기 정확률, 읽기 \\ 속도)의 차이}

본 연구에서 두 집단의 읽기유창성(분당 정확하게 읽은 음절수, 읽기 정확률, 읽기 속도)의 능력을 살펴보기 위하여 독립표본 $t$-검 정을 실시하였다. 집단과 읽기유창성의 $t$-검정 결과는 Table 2 와 같 이 나타났다.

언어학습장애 아동과 일반아동의 읽기유창성 능력에 차이가 있 는지 살펴본 결과, 언어학습장애 아동의 읽기유창성 능력은 분당 정확하게 읽은 음절수, 읽기 정확률, 읽기 속도 모두 일반아동보다 낮은 수행력을 보였다. 이러한 차이가 유의미한지 살펴본 결과, 분 당 정확하게 읽은 음절수, 읽기 정확률, 읽기 속도 각각 집단 간 유 의미한 차이를 보였다 $\left(t_{17}=-12.578, p<.001 ; t_{17}=-8.449, p<.001\right.$; $\left.t_{17}=8.166, p<.001\right)$.

\section{초등 3-4학년 아동의 집단(일반, 언어학습장애)에 따른 오류수의 차이 비교}

두 집단에서 나타나는 전체 오류수, 의미/음운 오류수에 차이가

Table 4. All error types ratio of each group

\begin{tabular}{lcc}
\hline & $L L D(N=17)$ & $T D(N=17)$ \\
\hline Omission & $16.82(9.313)$ & $11.60(8.986)$ \\
Addition & $8.39(7.584)$ & $14.98(18.445)$ \\
Substitution & $38.85(13.665)$ & $33.69(22.924)$ \\
Repeat & $26.93(13.733)$ & $29.85(14.394)$ \\
Self-correction & $9.52(2.847)$ & $24.78(18.637)$ \\
\hline
\end{tabular}

Values are presented as mean (SD).

$\mathrm{LLD}=$ language learning disabilities; $T D=$ typically developing children.

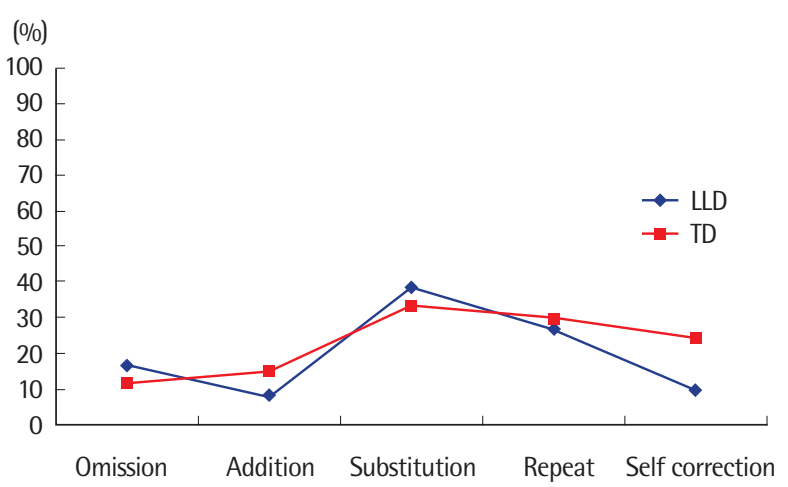

Figure 1. Total error type ratio of children with typically developing (TD) and language learning disabilities (LLD). 
Table 5. Semantic error types ratio of each group

\begin{tabular}{lcl}
\hline & LLD (N=17) & TD (N=17) \\
\hline Omission & $22.31(9.994)$ & $15.99(8.637)$ \\
Addition & $8.9(5.918)$ & $15.79(12.748)$ \\
Substitution & $40.5(9.550)$ & $28.45(15.806)$ \\
Repeat & $23.05(12.180)$ & $17.83(15.172)$ \\
Self-correction & $6.53(4.778)$ & $21.12(16.382)$ \\
\hline
\end{tabular}

Values are presented as mean (SD).

$L L D=$ language learning disabilities; $T D=$ children with typically developing .

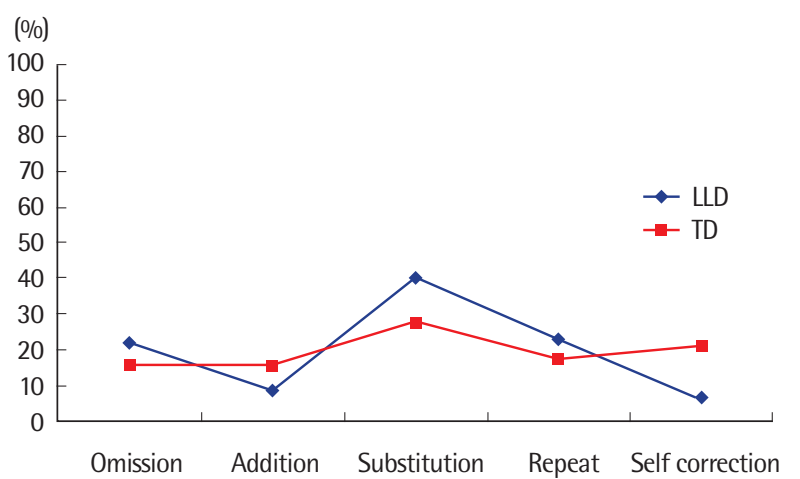

Figure 2. Semantic error type ratio of children with typically developing (TD) and language learning disabilities (LLD).

있는지 살펴보기 위하여 독립표본 $t$-검정을 실시하였다. 집단과 읽 기유창성의 $t$-검정 결과는 Table 3 과 같이 나타났다.

언어학습장애 아동과 일반아동의 전체 오류수, 의미/음운 오류 수에 차이가 있는지 살펴본 결과, 언어학습장애 아동의 전체 오류 수, 의미/음운 오류수 모두 일반아동에 비하여 낮은 수행력을 보였 다. 이러한 차이가 유의미한지 살펴본 결과, 전체 오류수, 의미/음운 오류수 각각 집단 간 유의한 차이를 보였다 $\left(t_{17}=8.395, p<.001\right.$; $\left.t_{17}=5.609, p<.001 ; t_{17}=7.459, p<.001\right)$.

\section{초등 3-4학년 아동의 집단(일반, 언어학습장애)에 따른 오류 유형의 차이 비교}

두 집단에게 나타나는 오류 유형의 비율을 살펴보기 위하여 전 체 오류, 의미/음운 오류 유형의 비율로 나누어 살펴보았다. 일반아 동과 언어학습장애 아동 각 집단의 전체 오류 유형의 비율에 대한 기술통계 결과는 Table 4, Figure 1과 같다.

언어학습장애 아동과 일반아동의 전체 오류 유형의 비율을 분 석한 결과, 일반아동은 대치, 반복, 자기수정, 첨가, 생략 순으로 나 타났고 언어학습장애 아동은 대치, 반복, 생략, 자기수정, 첨가 순으 로 나타났다.

오류는 언어적 특성을 고려하여 의미와음운으로 나누어 살펴보
Table 6. Phonological error types ratio of each group

\begin{tabular}{lcc}
\hline & $L \mathrm{LD}(\mathrm{N}=17)$ & $\mathrm{TD}(\mathrm{N}=17)$ \\
\hline Omission & $11.01(14.152)$ & $2.94(5.780)$ \\
Addition & $4.01(9.224)$ & $3.31(5.232)$ \\
Substitution & $31.76(18.600)$ & $27.99(23.222)$ \\
Repeat & $38.12(36.956)$ & $45.39(20.171)$ \\
Self-correction & $15.17(22.062)$ & $20.36(17.837)$ \\
\hline
\end{tabular}

Values are presented as mean (SD).

$\mathrm{LLD}=$ language learning disabilities; $\mathrm{TD}=$ children with typically developing .

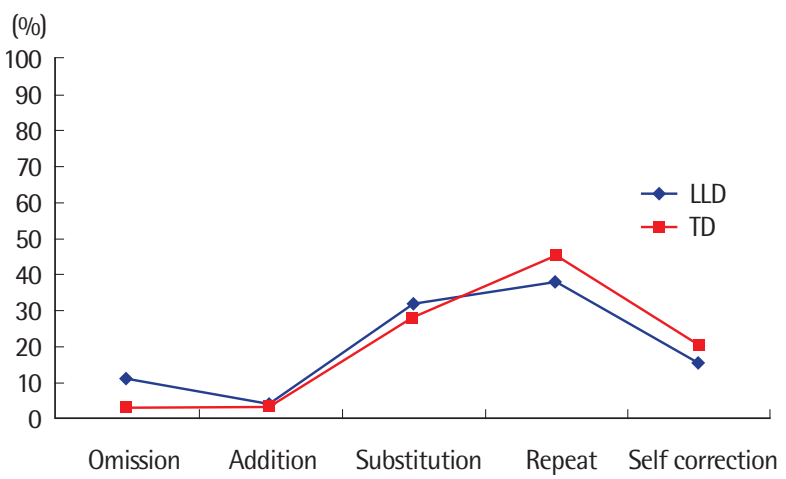

Figure 3. Phonological error type ratio of children with typically developing (TD) and language learning disabilities (LLD).

았다. 일반아동과 언어학습장애 아동 각 집단의 의미오류 유형의 비율에 대한 기술통계 결과는 Table 5, Figure 2와 같다.

언어학습장애 아동과 일반아동의 의미오류 유형의 비율을 분석 한 결과, 일반아동은 대치, 자기수정, 반복, 생략, 첨가 순으로 나타 났고 언어학습장애 아동은 대치, 반복, 생략, 첨가, 자기수정 순으로 나타났다.

일반아동과 언어학습장애 아동 각 집단의 음운오류 유형의 비 율에 대한 기술통계 결과는 Table 6, Figure 3과 같다.

언어학습장애 아동과 일반아동의 음운오류 유형의 비율을 분석 한 결과, 일반아동은 반복, 대치, 자기수정, 첨가, 생략 순으로 나타 났고 언어학습장애 아동은 반복, 대치, 자기수정, 생략, 첨가 순으로 나타났다.

\section{논의 및 결론}

본 연구는 초등 3-4학년 언어학습장애 아동과 일반아동의 읽기 유창성 능력을 살펴보고 오류 특성에 대하여 살펴보았다.

첫째, 두 집단의 분당 정확하게 읽은 음절수, 읽기 정확률, 읽기 속도를 비교하였을 때, 언어학습장애 아동이 일반아동보다 유의미 하게 낮은 것으로 나타났다. Chall (1983)의 읽기 발달 2단계는 유창 
성 단계로 이 시기의 읽기유창성의 어려움은 읽기이해로 전환되는 데 어려움을 보일 수 있다. 읽기유창성이란 빠르고 노력 없이 글을 자동적으로 읽는 능력으로 정확률, 자동성, 강세, 세기 등과 같은 다양한 요소를 가지고 있다(Kuhn \& Stahl, 2003; Logan, 1997). 읽 기부진 아동은 음운론적 능력의 결함으로 읽기문제가 시작되며 (Lyon, Shaywitz, \& Shaywitz, 2003), 의미능력과 음운능력의 어려 움으로 읽기유창성과 읽기이해에 제한을 보인다(Scarborough, 2001). 선행연구에서는 언어학습장애 아동 또는 읽기장애 아동을 대상으로 읽기유창성 평가를 한 결과, 일반아동보다 읽기유창성 (분당 정확하게 읽은 음절수, 정확도, 속도)에 어려움을 보고하였다 (Han \& Kim, 2018; Kim \& Seo, 2003; Kim \& Park, 2010). 본 연구 에서도 언어학습장애 아동이 일반아동보다 읽기유창성에 어려움 을 보이는 것을 확인하였다. 그러나 어휘와 학습능력에 유의한 차 이를 보이지 않는 장애집단인 $\mathrm{ADHD}$ 아동과 일반아동의 읽기유 창성 능력을 살펴본 선행연구에서는(Choi \& Jung, 2014; Kim et al., 2012) 두 집단 간 유의한 차이를 보이지 않았다. 이는 읽기유창성이 아동의 언어 및 읽기수준을 보여주는 능력이라는 것을 알 수 있었 으며 언어학습장애 아동의 읽기유창성 문제는 읽기의 최종목표인 읽기이해로 전환되는 데 어려움을 초래하므로 읽기이해에 도달하 기 전에 읽기유창성에 대하여 지원을 해주어야 한다.

읽기유창성은 읽기 정확률 $\times$ 읽기 속도로 정확률과 속도를 모두 갖추어야 한다. 그러나 언어 또는 읽기에 어려움을 보이는 아동은 음운능력의 제한을 가지고 읽기를 시작하며(Hogan, Catts, \& Little, 2005; Kim \& Kim, 2006; Lyon et al., 2003; Oh \& Lee, 2007), 저 학년 때 나타난 해독 능력의 결함이 중학년인 3-4학년 시기에도 나 타나 텍스트 수준에서 유창하게 글을 읽는 데 어려움을 보일 수 있 다. 본 연구에서도 언어학습장애 아동이 읽기 정확률에서 어려움 을 보였으므로 자동적 읽기를 위해 읽기 정확률을 지원해 주어야 한다. 그러나 정확하게 글을 읽더라도 글을 읽는 속도가 느리다면 읽기유창성에 어려움을 나타낼 수 있으며(Morris et al., 1998), Wolf, Bowers와 Biddle (2000)은 읽기이해의 어려움을 음운해독뿐 아니 라 느린 속도로 인해 발생할 수 있다고 하였다. Kim (2017)의 연구 에서 초등 3 학년은 어휘와 음운처리를 바탕으로 읽기 속도를 향상 시키지만 4학년에 올라가서는 어휘능력, 글자 읽기능력을 바탕으 로 속도를 향상시킨다고 한다. 즉, 속도는 언어처리 능력과 음운해 독 능력에 영향을 받으며 어떤 변인이 읽기 속도를 향상시키는지 자 세하게 살펴보기 위해서는 속도만을 따로 측정하고 지원하는 것이 필요하다고 하였다. 따라서 읽기유창성을 읽기 정확률과 읽기 속도 로 나누어 세부적으로 살펴보는 것이 필요하며 어떤 변인이 읽기유 창성에 영향을 미치는지 고려해야 한다.
둘째, 언어학습장애 아동은 일반아동보다 전체 오류수, 의미/음 운 오류수가 유의미하게 높았다. 이는 앞서 살펴본 읽기 정확률의 결과와 같이 언어학습장애 아동이 오류의 수가 더 많이 나타났음 을 확인하였다. 해독 능력과 언어처리 능력의 문제는 읽기 정확률 과 읽기 속도에 영향을 미치므로 두 가지를 활용하여 오류를 감소 해야 유창하게 읽을 수 있다. 읽기유창성의 핵심적 요소는 자동성 이며 자소와 음운을 포함한 어휘능력이 이러한 자동성에 영향을 미친다. 그리고 새로운 낱말을 읽을 수 있도록 하는 음운인식 능력 이 읽기유창성에 영향을 미치게 된다(Jenkins et al., 2003). 따라서 읽기유창성은 의미경로와 음운경로가 모두 필수적 요인이다. 그러 나 언어적 능력의 결함을 가진 언어학습장애 아동은 의미/음운 능 력의 어려움으로 읽기유창성에 영향을 미칠 것이다. 따라서 이러한 언어와 읽기의 결함이 읽기유창성에 어떠한 영향을 미치는지 자세 하게 살펴보기 위해 읽기유창성을 양적 분석뿐 아니라 언어 특성 을 고려하여 의미와 음운으로 나누어 오류를 확인하는 것이 중요 하다.

두 집단의 읽기 특성을 자세하게 살펴보기 위해 읽기 오류 유형 을 전체, 의미/음운으로 나누어 확인하였다.

전체 오류 유형의 비율을 구체적으로 살펴본 결과, 두 집단 모두 대치가 가장 높은 비율로 나타났고, 그 다음으로 일반아동은 반복, 자기수정, 첨가, 생략 순으로 나타났고 언어학습장애 아동은 반복, 생략, 자기수정, 첨가 순으로 나타났다. 대치는 음소, 음절, 단어, 어 절 단위에서 의미단어로 대치한 것으로 선행연구에서는 읽기에 어 려움을 보이는 집단에서 오류 유형 중 대치가 가장 많이 나타난다 고 하였다(Kim et al., 2010; Woo \& Kim, 2012). 본 연구 결과에서 도 언어학습장애 아동(38.85\%)과 일반아동(33.69\%) 모두 대치 오 류가 가장 많았으며 텍스트에서 글자의 자동적 읽기를 위한 평가 및 지원이 필요하다는 것을 확인하였다. 선행연구에서는 읽기장애 아동에서 나타나는 반복 오류는 학년이 올라갈수록 증가하였으며 이는 어려운 단어를 되풀이하여 읽는 것으로 글을 읽으려는 시도 라고 하였다(Woo \& Kim, 2012). 본 연구에서도 언어학습장애 아 동에게서 반복의 오류가 오류 유형 중 2 번째로 나타났다는 것을 확 인하였다. 자기수정은 선행연구에서 유창하게 읽는 집단에서 빈번 하게 나타나는 오류로 상대적으로 심각성이 덜한 오류라고 하였다 (Hoffman \& Clements, 1984; Weber, 1970). 본 연구결과에서도 일 반아동은 $24.78 \%$, 언어학습장애 아동은 $9.52 \%$ 로 나타나 선행연구 의 결과와 일치한 부분을 확인하였다. 따라서 일반아동은 글을 읽 으면서 자신의 오류를 확인하는 모습을 보였고, 언어학습장애 아 동은 자신의 오류를 확인하는 것에 어려움을 보인다는 것을 알 수 있었다. 생략은 음절구조에 변화를 주는 오류로 학령기 초기에 빈 
번하게 나타나며 학년이 올라갈수록 점점 감소한다고 한다(Pae, 2004). 본 연구에서도 일반아동은 생략이 가장 낮은 비율로 나타났 으나 언어학습장애 아동은 초등 중학년인 3-4학년이 되어서도 복 잡한 단어에서 음절을 생략하는 오류가(16.82\%) 나타나고 있었다. 첨가는 읽기장애와 일반아동의 오류 유형을 확인한 선행연구 (Kim et al., 2010)에서 두 집단 모두 가장 낮은 비율로 나타났으며 본 연구에서도 언어학습장애 아동은 오류 유형 중 첨가가 가장 낮 은 비율로 나타났다는 것을 확인하였다. 언어학습장애 아동은 제 한된 언어능력으로 일반아동보다 사용하는 언어적 용량 범위가 작 으므로 상대적으로 음절을 추가하는 모습이 많이 나타나지 않았 다는 것을 살펴볼 수 있었다.

의미오류의 비율에서 일반아동은 대치, 자기수정, 반복, 생략, 첨 가 순으로 나타났고, 언어학습장애 아동은 대치, 반복, 생략, 첨가, 자기수정 순으로 나타났다. 의미오류의 대치는 의미적으로 타당한 어휘를 예측하는 데 오류를 보이는 것을 포함하며(예: 오후 $\rightarrow$ 오전), 두 집단 모두 대치가 가장 높은 비율로 나타났다. 따라서 글을 의미 적으로 알맞은 어휘로 예측하여 읽는 어려움을 보이는 것으로 글 을 자동적으로 읽기 위해 예측하여 글을 읽는 확인이 필요하였다. 자기수정은 의미 있는 다른 단어로 읽고 난 후 되돌아와서 정확하 게 읽는 오류로(예: 안에는 $\rightarrow$ 안에서 안에는) 능숙한 읽기자가 읽음 과 동시에 문맥을 이해하고 있을 때 나타나는 것으로 좋은 신호라 고 볼 수 있다(Burns \& Roe, 2002). 본 연구에서는 언어학습장애 아동이 가장 낮은 비율로 자기수정이 나타났으며 이는 의미적으로 글을 이해하면서 모니터링하는 데 어려움을 보인다는 것으로 살펴 볼 수 있었다. 반복은 단어, 어절 단위를 반복하여 읽는 것으로(예: 대신에 $\rightarrow$ 대신 대신에) 의미적 단위로 글을 되풀이하여 읽으나 속도 를 저하시켜 자동성에 영향을 줄 것이다. 학년이 증가하면서 문맥 의 의미를 변화시키지 않는 반복오류는 상대적으로 증가한다는 선 행연구의 결과를 보았을 때(Kim et al., 2010), 본 연구결과에서 언 어학습장애 아동은 $23.05 \%$ 반복의 오류가 나타남을 확인하였다. 의미오류에서 생략은 음절구조를 빠뜨려 읽는 생략(예: 집에서는 $\rightarrow$ 집에서)으로 선행연구에서는 읽기자가 의미를 재구성해 나가는 과 정에서 자연스럽게 나타나는 오류라고 하였다(Park, 2000). 본 연 구에서는 언어학습장애 아동(22.31\%)과 일반아동(15.99\%) 모두 전체 오류에서의 생략보다 의미오류에서의 생략이 더 높게 나타났 으며 이는 의미적으로 글을 읽음으로써 나타나는 오류라는 것을 확인하였다. 첨가는 의미적으로 음절구조를 추가해서 읽는 오류로 (예: 7시에 $\rightarrow 7$ 시에는) 언어학습장애 아동은 $8.9 \%$ 로 의미오류 유형 중 4 번째로 나타났다. 이는 읽기능력이 낮은 집단은 해독하는 데 집 중을 하기 때문에 음절구조를 첨가하는 오류가 상대적으로 적었
다(Pae, 2004)는 선행연구와 일치하였다. 따라서 읽기능력이 낮은 집단은 음절구조를 첨가하는 오류가 상대적으로 적었으며 언어학 습장애 아동은 제한된 언어능력으로 음절구조를 첨가하면서까지 읽기오류를 나타내지 않는다는 것을 확인할 수 있었다.

음운오류의 비율은 일반아동이 반복, 대치, 자기수정, 첨가, 생략 순으로 나타났고 언어학습장애 아동이 반복, 대치, 자기수정, 생략, 첨가 순으로 나타났다. 대치는 음운규칙을 적용하지 않거나 음소, 음절, 단어, 어절 단위에서 무의미한 단어로 대치한 경우를 포함한 다(예: 오늘이[오느리] $\rightarrow$ 오늘이[오늘이], 오늘이 $\rightarrow$ 오늘우). 선행연구 에서는 읽기부진 아동이 일반아동보다 음운변동 규칙을 지키는 데 어려움을 보이며 단어해독 능력에 제한을 보였다(Kim \& Park, 2010; Park, 2000). 본 연구에서도 두 집단 모두 각 집단에서 음운오 류 유형 중 2 번째로 대치의 오류를 보였으며 이는 정확하게 글을 읽 기 위해서는 철자와 음운의 대응관계를 지원해 주어야 한다는 것 을 확인하였다. 반복은 음운 단위에서 글자를 자동적으로 읽는 데 어려움을 보이는 오류로(예: 장마 $\rightarrow$ 장장마) 두 집단 모두 가장 높은 비율로 나타났다. 앞에서 살펴본 선행연구와 같이 반복오류가 높게 나타난다는 것은 어려운 단어를 읽으려는 시도로 확인되었다 (Woo \& Kim, 2012). 의미오류에서는 두 집단 모두 대치가 가장 높 은 비율로 나타났으나 음운오류에서는 글자 자체를 틀리게 읽는 해 독의 어려움보다는 자동성에 영향을 미치는 반복이 가장 높은 비 율로 나타났다. 따라서 의미, 음운의 언어능력에 따라 글 읽기에 영 향을 받을 것으로 확인되며 특히 언어 문제를 동반한 언어학습장 애 아동의 글 읽기에 집중해야 할 것이다. 자기수정은 글자를 틀리 게 읽고 난 후 다시 정확하게 읽는 오류로(예: 소리가 $\rightarrow$ 소래가) 언어 학습장애 아동은 의미오류(6.53\%)보다 음운오류(15.17\%)에서 자 기수정이 더 높았다. 이는 의미적 단위가 아닌 음운적 단위에서 글 자와 음운에 대한 모니터링이 어느 정도 가능하다는 것을 확인할 수 있었다. 첨가는 음소, 음절, 단어, 어절 단위에서 무의미 단어로 첨가한 경우(예: 한숨을 $\rightarrow$ 한숨에을)이다. 선행연구에서 읽기장애 아동은 초등학교 4 학년이 되어서도 음운처리 능력의 결함으로 인 하여 음소 첨가 과제에서 어려움을 보인다고 하였다(Kim \& Seo, 2003). 본 연구에서도 언어와 읽기에 결함을 보이는 언어학습장애 아동이 해독에 집중하여 글을 읽기 때문에 글자 자체를 추가하여 읽는 것이 가장 낮은 비율로 나타났다는 것을 확인하였다. 생략은 음소, 음절, 단어, 어절 단위에서 무의미 단어로 생략한 오류(예: 토 요일 $\rightarrow$ 토요이)이며 선행연구에서 읽기능력이 낮은 학습자는 읽기 어려운 어휘를 만났을 때, 생략해 버리는 습관이 있다고 한다 (Howell, Fox, \& Morehead, 1993). 본 연구에서 언어학습장애 아동 의 생략 오류가 $11.01 \%$ 로 나타났는데 이는 복잡한 음절구조에서 
음절을 빠뜨려 읽는 모습이 나타나 문맥의 흐름을 방해하는 경우 가 많았을 것으로 확인하였고 이에 대한 지원이 필요할 것이다.

본 연구에서는 읽기유창성 특성과 읽기 오류 특성에 대하여 살 펴보았다. 문단글 수준의 읽기유창성을 따로 살펴보기 위해서 이후 연구에서는 언어학습장애 아동의 해독 발달을 고려하여 낱말수준 에서의 해독 능력을 통제하여 살펴볼 필요가 있음을 제언한다. 또 한 읽기 오류 특성을 구체적으로 살펴보기 위해 언어적 요소에 따 라 내용어와 기능어로 나누어 확인해 볼 후속연구를 제안한다.

\section{REFERENCES}

Bashir, A. S., \& Hook, P. E. (2009). Fluency: a key link between word identification and comprehension. Language, Speech, and Hearing Services in Schools, 40(2), 196-200.

Bishop, D. V., \& Adams, C. (1992). Comprehension problems in children with specific language impairment: literal and inferential meaning. Journal of Speech, Language, and Hearing Research, 35(1), 119-129.

Bradley, L., \& Bryant, P. E. (1983). Categorizing sounds and learning to read: a causal connection. Nature, 301(5899), 419-421.

Burns, P. C., \& Roe, B. D. (2002). Burns/Roe informal reading inventory: preprimer to twelfth grade (6th ed.). Boston, MA: Houghton Mifflin.

Castles, A., Bates, T., Coltheart, M., Luciano, M., \& Martin, N. G. (2006). Cognitive modelling and the behaviour genetics of reading. Journal of Research in Reading, 29(1), 92-103.

Catts, H. W., Fey, M. E., Tomblin, J. B., \& Zhang, X. (2002). A longitudinal investigation of reading outcomes in children with language impairments. Journal of Speech, Language, and Hearing Research, 45(6), 1142-1157.

Chall, J. S. (1983). Stages of reading development. New York, NY: McGrawHill.

Choi, Y. K., \& Jung, H. Y. (2014). A comparative study on reading fluency and reading comprehension between ADHD children and non-ADHD children. Journal of Emotional \& Behavioral Disorders, 30(4), 133-152.

Fuchs, L. S., Fuchs, D., Hosp, M. K., \& Jenkins, J. R. (2001). Oral reading fluency as an indicator of reading competence: a theoretical, empirical, and historical analysis. Scientific Studies of Reading, 5(3), 239-256.

German, D. J., \& Simon, E. (1991). Analysis of children's word-finding skills in discourse. Journal of Speech, Language, and Hearing Research, 34(2), 309-316.

Goswami, U., \& Bryant, P. (1990). Phonological skills and learning to read. Hove, UK: Lawrence Erlbaum.
Gough, P. B., \& Tunmer, W. E. (1986). Decoding, reading, and reading disability. Remedial and Special Education, 7(1), 6-10.

Han, H. J., \& Kim, M. (2018). Correlation among morphological awareness, reading fluency and spelling for school-aged children with language-learning disabilities in third to fourth grades. Communication Sciences \& Disorders, 23(2), 347-359.

Hoffman, J. V., \& Clements, R. (1984). Reading miscues and teacher verbal feedback. The Elementary School Journal, 84(4), 423-439.

Hogan, T. P., Catts, H. W., \& Little, T. D. (2005). The relationship between phonological awareness and reading. Language, Speech, and Hearing Services in Schools, 36(3), 285-293.

Howell, K. W., Fox, S. L., \& Morehead, M. K. (1993). Curriculum-based evaluation: teaching and decision making. Pacific Grove, CA: Brooks.

Hudson, R. F., Lane, H. B., \& Pullen, P. C. (2005). Reading fluency assessment and instruction: what, why, and how? The Reading Teacher, 58(8), 702-714.

Jenkins, J. R., Fuchs, L. S., Van Den Broek, P., Espin, C., \& Deno, S. L. (2003). Accuracy and fluency in list and context reading of skilled and RD groups: absolute and relative performance levels. Learning Disabilities Research \& Practice, 18(4), 237-245.

Jeong, J. S. (2013). An examination of the hierarchy of readability levels of text selections in elementary reading textbooks. The Korea Journal of Learning Disabilities, 10(1), 31-50.

Kamhi, A. G., \& Catts, H. W. (2012). Language and reading disabilities (3rd ed.). Boston: Allyn and Bacon.

Kim, A. H., \& Hwang, M. (2008). Prediction of reading skills in upper elementary students. Korean Journal of Communication \& Disorders, 13(1), $1-25$.

Kim, A. H., \& Park, S. H. (2010). Reading fluency of elementary students with and without reading disabilities: reading developmental patterns and error patterns. Journal of Special Education: Theory and Practice, 11(4), 323-344

Kim, A. H., Kim, U. J., Hwang, M., \& Yoo, H. S. (2014). Test of Reading Achievement and Reading Cognitive Processes Ability. Seoul: Hakjisa.

Kim, A. H., Park, S. H., \& Kim, J. H. (2010). Reading fluency of elementary students in Korea: reading developmental patterns and error patterns. Korean Journal of Communication \& Disorders, 15(1), 43-55.

Kim, D. I. (2008). Basic Academic Skills Assessment (BASA): reading. Seoul: Hakjisa.

Kim, M. (2017). Correlations between the reading accuracy, speed, and lin- 
guistic ability in elementary 3rd and 4th graders. Journal of the Korean Data Analysis Society, 19(2), 957-970.

Kim, M., \& Pae, S. (2012). Reading skills and phonological processing abilities of Korean elementary school children with/without poor reading. Korean Journal of Communication \& Disorders, 17(4), 565-581.

Kim, M., \& Seo, G. H. (2003). A study of phonological awareness and reading fluency in children with reading disabilities. Journal of Emotional \& Behavioral Disorders, 19(4), 381-399.

Kim, W. S., \& Kim, Y. T. (2006). Variables related to the word recognition and reading comprehension of Korean children with specific language impairment. Korean Journal of Communication \& Disorders, 11(3), 47-63.

Kim, Y. E., Pae, S., \& Kim, M. (2012). Word recognition and paragraph reading fluency of third-and fourth-graders with ADHD. Journal of Speech \& Hearing Disorders, 21(3), 283-296.

Kuhn, M. R., \& Stahl, S. A. (2003). Fluency: a review of developmental and remedial practices. Journal of Educational Psychology, 95(1), 3-21.

Lee, E. J. (2014). Relations between story comprehension and working memory abilities of third-graders (Master's thesis). Chungnam National University, Daejeon, Korea.

Lee, J. Y., \& Kim, W. S. (2012). Reading fluency characteristics of 2-3th grade children with attention deficit hyperactivity disorder. Journal of Speech \& Hearing Disorders, 21(4), 191-208.

Lee, Y., Heo, H., \& Jang, S. (2015). Language Scale for School-aged Children (LSSC). Seoul: Hakjisa.

Liberman, I. Y., \& Liberman, A. M. (1990). Whole language vs. code emphasis: underlying assumptions and their implications for reading instruction. Annals of Dyslexia, 40(1), 51-76.

Logan, G. D. (1997). Automaticity and reading: perspectives from the instance theory of automatization. Reading \& Writing Quarterly: Overcoming Learning Difficulties, 13(2), 123-146.

Lyon, G. R., Shaywitz, S. E., \& Shaywitz, B. A. (2003). A definition of dyslexia. Annals of Dyslexia, 53(1), 1-14.

MacLachlan, B. G., \& Chapman, R. S. (1988). Communication breakdowns in normal and language learning-disabled children's conversation and narration. Journal of Speech and Hearing Disorders, 53(1), 2-7.

McKenna, M. C., \& Picard, M. C. (2006). Revisiting the role of miscue analysis in effective teaching. The Reading Teacher, 60(4), 378-380.

Merritt, D. D., \& Liles, B. Z. (1987). Story grammar ability in children with and without language disorder: story generation, story retelling, and story comprehension. Journal of Speech, Language, and Hearing Research, 30(4),
$539-552$

Morris, R. D., Stuebing, K. K., Fletcher, J. M., Shaywitz, S. E., Lyon, G. R., Shankweiler, D. P., ... \& Shaywitz, B. A. (1998). Subtypes of reading disability: variability around a phonological core. Journal of Educational Psychology, 90(3), 347-373.

Norbury, C. F., \& Bishop, D. V. (2002). Inferential processing and story recall in children with communication problems: a comparison of specific language impairment, pragmatic language impairment and high-functioning autism. International Journal of Language \& Communication Disorders, 37(3), 227-251.

Oh, H. J., \& Lee, Y. K. (2007). Reading ability of Korean lower graders with specific language impairment. Journal of Speech \& Hearing Disorders, 16(4), 61-74.

Pae, H. S. (2004). Analysis of reading errors by reading abilities in early childhood (Master's thesis). Seoul National University, Seoul, Korea.

Pae, S., Kim, M., Yoon, H. J., \& Jang, S. (2015). Korean Language Based Reading Assessment (KOLRA). Seoul: Hakjisa.

Pae, S., Shin, G., Seol, A., Pae, S., Shin, G., \& Seol, A. (2017). Developmental characteristics of word decoding and text reading fluency among Korean children with developmental dyslexia. Communication Sciences \& Disorders, 22(2), 272-283.

Park, H. (2014). Korean version of Comprehensive Test of Nonverbal Intelligence Second Edition (K-CTONI-2). Seoul: Mindpress.

Park, H. S. (2000). Reading Error Type Assessment Instructor's Guide. Seoul: Paradise Welfare Foundation.

Paul, R., \& Norbury, C. F. (2012). Language disorders from infancy through adolescence (4th ed.). St. Louis, MO: Elsevier Health Sciences.

Pennington, B. F., \& Bishop, D. V. (2009). Relations among speech, language, and reading disorders. Annual Review of Psychology, 60, 283-306.

Quinn, J. M., Wagner, R. K., Petscher, Y., \& Lopez, D. (2015). Developmental relations between vocabulary knowledge and reading comprehension: a latent change score modeling study. Child Development, 86(1), 159-175.

Rescorla, L. (2005). Age 13 language and reading outcomes in late-talking toddlers. Journal of Speech, Language, and Hearing Research, 48(2), 459472 .

Scarborough, H. S. (2001). Connecting early language and literacy to later reading (dis)abilities: evidence, theory, and practice. In S. B. Neuman \& D. K. Dickinson (Eds.). Handbook of early literacy research (pp. 97-110). New York, NY: Guilford Press.

Scarborough, H. S., \& Dobrich, W. (1990). Development of children with 
early language delay. Journal of Speech, Language, and Hearing Research, 33(1), 70-83.

Shaywitz, S. E., Escobar, M. D., Shaywitz, B. A., Fletcher, J. M., \& Makuch, R. (1992). Evidence that dyslexia may represent the lower tail of a normal distribution of reading ability. New England Journal of Medicine, 326(3), 145-150.

Shim, G., \& Jung, K. H. (2012). Reading fluency of first and second grade children from multicultural backgrounds. Journal of Speech \& Hearing Disorders, 21(2), 93-110.

Silberglitt, B., \& Hintze, J. (2005). Formative assessment using CBM-R cut scores to track progress toward success on state-mandated achievement tests: a comparison of methods. Journal of Psychoeducational Assessment, 23(4), 304-325.

Silliman, E. R., Butler, K. G., \& Wallach, G. P. (2001). The time has come to talk of many things. In K. G. Butler \& E. R. Silliman (Eds.), Speaking, reading, and writing in children with language learning disabilities (pp. 15-38). Mahwah, NJ: Lawrence Erlbaum Associates.

Stein, N. L., \& Glenn, C. G. (1975). An analysis of story comprehension in elementary school children: a test of a schema. St. Louis, MO: Washington University.

Storch, S. A., \& Whitehurst, G. J. (2002). Oral language and code-related precursors to reading: evidence from a longitudinal structural model. Developmental Psychology, 38(6), 934-947.

Torgesen, J. K., \& Hudson, R. (2006). Reading fluency: critical issues for strug- gling readers. In S. J. Samuels and A. Farstrup, A. (2006). Reading fluency: the forgotten dimension of reading success (pp. 130-158). Newark, DE: International Reading Association.

Vellutino, F. R., Tunmer, W. E., Jaccard, J. J., \& Chen, R. (2007). Components of reading ability: multivariate evidence for a convergent skills model of reading development. Scientific Studies of Reading, 11(1), 3-32.

Weber, R. M. (1970). A linguistic analysis of first-grade reading errors. Reading Research Quarterly, 5(3), 427-451.

Wolf, M. (2007). Proust and the squid: the story and science of the reading brain. New York, NY: HarperCollins Publishers.

Wolf, M., Bowers, P. G., \& Biddle, K. (2000). Naming-speed processes, timing, and reading: a conceptual review. Journal of Learning Disabilities, 33(4), 387-407.

Woo, J. H., \& Kim, S. S. (2010). A study on language ability and reading ability of children with reading disability. Journal of Special Education: Theory and Practice, 11(3), 163-183.

Woo, J. H., \& Kim, S. S. (2012). A study of reading characteristics of students with reading disabilities: analyses of reading disability type, reading miscue type and text comprehension ability. Special Education \& Rehabilitation Science, 51(3), 197-218.

Yun, H. R. (2005). Story comprehension and retelling abilities in school-age children with specific language impairment (Doctoral dissertation). Ewha Woman University, Seoul, Korea. 
Appendix 1. 읽기유창성 과제

\section{은지의 주말 이야기}

장마가 끝난 어느 토요일 오후에 은지는 경수와 물놀이를 가기로 했어요. 두 친구가 그 곳에 도착했을 때, 둘은 매우 목이 말랐어요. 경수는 자기 가방에서 음료 수를 꺼내서 은지에게 나눠 주었어요. 오렌지 주스는 아주 시원했어요.

은지는 화장실에 들어가서 파란색 원피스를 벗고 수영복으로 갈아 입었어요. 그런데 파도가 너무 심해서 물놀이를 할 수 없었어요. 그래서 물놀이 대신에 모래 성 쌓기를 했어요. 두 친구는 오후 내내 정신없이 노느라고 다른 일들은 모두 잊어버렸어요.

갑자기 은지는 오늘이 은지 동생의 생일인 것이 기억났어요. 은지 집에서는 보통 7시에 저녁을 먹지만, 특별한 날에는 한 시간 일찍 식사를 해요. 은지는 얼른 수영복을 벗어 수건 안에 둘둘 말아 배낭 속에 집어넣었어요. 그런 다음 서둘러 옷을 갈아입고 집으로 출발했어요. 그들은 있는 힘껏 최대한의 속도로 페달을 밟았어요.

집에 도착했을 때 은지는 매우 피곤했지만, 저녁식사 시간을 정확히 맞출 수 있었어요. 벌써 다른 가족들은 모두 식탁에 둘러 앉아 있었어요. 은지는 얼른 자기 방으로 들어가 책상 서랍 안에서 미리 포장해 놓은 크레파스를 꺼냈어요. 은지가 식탁에 앉으니 엄마는 케이크에 꽃혀진 다섯 개의 초에 불을 붙였어요. 은지는 “휴우”하고 안도의 한숨을 쉬었어요.

\section{삼형제 이야기}

옛날에 낚시를 좋아하는 삼형제가 이침 일찍 배를 타고 바다에 낚시를 하러 갔어요. 부드러운 바람결에 삼형제는 모두 깊이 잠이 들어버렸어요. 그런데 그들이 잠든 사이에 한밤중이 되었고, 갑자기 폭풍우가 몰아쳤어요. 그래서 그만 돛이 부러지고 배는 커다란 바위에 부딪혀 버렸어요.

형제들은 깜짝 놀라 잠에서 깨었어요. 그리고는 부서진 배로부터 멀지 않은 곳에 섬 하나가 있는 것을 보았어요. 그들은 있는 힘을 다해 헤엄을 쳤고 섬에 도착 하자 삼형제는 모두 살아 있는 것에 감격했어요. 그러나 곧 그들이 무인도에 버려졌다는 것을 알게 되었어요.

섬에서의 생활은 처음에는 매우 어려웠어요. 무엇보다도 먹을 것이 아무 것도 없었어요. 그러나 힘을 모아 노력한 끝에 그들은 드디어 물과 음식을 구할 수 있 었어요. 코코넛에는 물이 들어있었고, 물고기를 구웠더니 맛있는 요리가 되었어요. 그들은 더 이상 배고프지 않았어요.

그러던 어느 날 멀리서 배의 소리가 들렸어요. 그래서 형제들은 배가 지나간다는 것을 알게 되었어요. 형제들은 얼른 나무를 모아 불을 붙이자 곧바로 검은 연 기가 하늘 높이 피어올랐어요. 고기잡이 배의 선장이 그것을 보고 선원들을 섬으로 보냈어요. 거기에서 선원들은 세 형제로부터 큰 환영을 받았어요.

Appendix 2. 읽기유창성 과제 이야기글 구성

\begin{tabular}{lcc}
\hline & 은지의 주말 이야기 & 삼형제 이야기 \\
\hline 에피소드 수 & 4 & 4 \\
문장 수 & 18 & 18 \\
단문 수 & 5 & 5 \\
복문 수 & 13 & 13 \\
어절 수 & 159 & 150 \\
문장 내 평균 어절 수 & 8.8 & 8.3 \\
음절 수 & 456 & 448 \\
문장 내 평균 음절 수 & 25.3 & 24.9 \\
\hline
\end{tabular}


Appendix 3. 읽기 오류 유형 분석기준

\begin{tabular}{|c|c|c|c|}
\hline 오류 & & 조작적 정의 & 예 \\
\hline \multirow[t]{5}{*}{ 의미 오류 } & 생략 & 음소, 음절, 단어, 어절 단위에서 의미 단어로 생략한 경우 & 사람들이[사람드리] $\rightarrow$ 사람이[사라미] \\
\hline & 첨가 & 음소, 음절, 단어, 어절 단위에서 의미 단어로 첨가한 경우 & 사람들이[사람드리] $\rightarrow$ 사람들이랑[사람드리랑] \\
\hline & 대치 & 음소, 음절, 단어, 어절 단위에서 의미 단어로 대치한 경우 & 사람들이[사람드리] $\rightarrow$ 사과들이[사과드리] \\
\hline & 반복 & 단어, 어절 단위에서 반복한 경우 & 사람들이[사람드리] $\rightarrow$ 사람사람들이[사람사람드리] \\
\hline & 자기수정 & 음소, 음절, 단어, 어절 단위에서 의미 단어로 수정한 경우 & 사람들이[사람드리] $\rightarrow$ 사람이 사람들이[사라미 사람드리] \\
\hline \multirow[t]{6}{*}{ 음운 오류 } & 생략 & 음소, 음절, 단어, 어절 단위에서 무의미 단어로 생략한 경우 & 사람들이[사람드리] $\rightarrow$ 사라들이[사라드리] \\
\hline & 첨가 & 음소, 음절, 단어, 어절 단위에서 무의미 단어로 첨가한 경우 & 사람들이[사람드리] $\rightarrow$ 삼람들이[삼람드리] \\
\hline & 대치 & 음소, 음절, 단어, 어절 단위에서 무의미 단어로 대치한 경우 & 사람들이[사람드리 $] \rightarrow$ 사잠들이[사잠드리 $]$ \\
\hline & & 음운규칙 미적용 & 사람들이[사람드리] $\rightarrow$ 사람들이[사람들이] \\
\hline & 반복 & 음소, 음절 단위에서 반복한 경우 & 사람들이[사람드리] $\rightarrow$ 사사람들이[사사람드리] \\
\hline & 자기수정 & 음소, 음절, 단어, 어절 단위에서 무의미 단어로 수정한 경우 & 사람들이 $[$ 사람드리 $] \rightarrow$ 사잠들이 사람들이 $[$ 사잠드리 사람드리 $]$ \\
\hline
\end{tabular}




\title{
국문초록
}

\author{
초등 3-4학년 언어학습장애 아동의 읽기유창성과 의미/음운 오류 특성 \\ 채시화' $\cdot$ 김미배2 \\ '부산가톨릭대학교 대학원 언어청각치료학과, ${ }^{2}$ 다온언어학습연구소
}

배경 및 목적: 초등 3-4학년은 읽기유창성이 완성되는 시기로 읽기의 최종목표인 읽기이해에 도달하기 전에 읽기유창성이 선행되어야 한다. 따라서 언어문제를 동반한 언어학습장애 아동들의 읽기유창성 능력을 살펴보고 오류 특성을 구체적으로 알아보았다. 방법: 초 등학교 3-4학년에 재학 중인 언어학습장애 아동 17 명, 학년과 지역을 일치시킨 일반아동 17 명, 총 34 명으로 하였다. 읽기유창성은 이야 기글 2개로 살펴보았으며 분당 정확하게 읽은 음절수, 정확률, 속도로 살펴보았고 오류는 의미/음운 오류로 나누어 오류수, 오류 유형을 살펴보았다. 결과: 언어학습장애 아동의 읽기유창성을 살펴본 결과 분당 정확하게 읽은 음절수, 정확률, 속도가 일반아동보다 유의미 하게 낮았다. 또한 전체, 의미/음운 오류수 모두 유의미하게 높았다. 오류 유형을 살펴보자면 의미오류는 대치가 가장 많이 나타났으며 일반아동은 자기수정, 반복, 생략, 첨가 순으로 언어학습장애 아동은 반복, 생략, 첨가, 자기수정 순으로 나타났다. 음운오류는 반복, 대 치, 자기수정이 공통적으로 나타났고 일반아동은 첨가, 생략 순으로 언어학습장애 아동은 생략, 첨가 순으로 나타났다. 논의 및 결론: 본 연구에서는 초등 3-4학년 언어학습장애 아동의 읽기유창성과 의미/음운 오류 특성에 대하여 확인하였다. 언어와 읽기에 어려움을 보이는 언어학습장애 아동은 글을 자동적으로 읽는 데 어려움을 보였으며 의미/음운 오류의 특성이 두드러지는 것으로 나타나 평가와 중재에서 이를 고려하여 읽기유창성을 확인해야 할 것이다.

핵심어: 언어학습장애, 읽기유창성, 정확률, 속도, 의미/음운 오류, 오류 유형

본 연구는 제 1 저자의 석사학위논문을 수정 및 보완하였음.

\section{참고문헌}

김동일(2008). 기초학습기능 수행평가체제(BASA): 읽기검사. 서울: 학지사.

김미경, 서경희(2003). 읽기장애 아동의 음운인식능력과 읽기유창성 연구. 정서·행동장애연구, 19(4), 381-399.

김미배(2017). 초등 3-4학년 아동의 문단글 읽기 정확성, 속도와 언어능력 간의 관계. 한국자료분석학회, 19(2), 957-970.

김미배, 배소영(2012). 초등 읽기부진 아동의 읽기특성. 언어청각장애연구, 17(4), 565-581.

김애화, 김의정, 황민아, 유현실(2014). 읽기 성취 및 읽기 인지처리능력 검사(RA-RCP). 서울: 학지사.

김애화, 박성희(2010). 초등학교 읽기장애 학생과 일반 학생의 읽기 유창성 특성 및 오류 유형 비교 연구. 특수교육저널: 이론과 실천, 11(4), 323-344. 김애화, 박성희, 김주현(2010). 초등학생의 읽기유창성 특성 연구: 읽기유창성 발달 패턴 및 오류 유형 분석. 언어청각장애연구, 15(1), 43-55. 김애화, 황민아(2008), 초등학교 고학년의 읽기능력에 영향을 미치는 읽기관련 변인에 관한 연구. 언어청각장애연구, 13(1), 1-25. 김용은, 배소영, 김미배(2012). 초등 3-4학년 ADHD 아동의 낱말재인 및 문단 글 읽기 유창성. 언어치료연구, 21(3), 283-296. 김화수, 김영태(2006). 단순언어장애 아동의 읽기특성 변인. 언어청각장애연구, 11(3), 47-63.

박현숙(2000). 읽기 오류 유형 평가-교수 활용을 위한 지침서. 서울:파라다이스 복지재단.

박혜원(2014). 한국 비언어지능검사 2판(K-CTONI-2). 서울: 마인드프레스.

배소영, 김미배, 윤효진, 장승민(2015). 한국어 읽기검사(KOLRA). 서울: 학지사.

배소영, 신가영, 설아영(2017). 한국 발달성 난독 학생의 해독 및 읽기유창성 발달 특성. Communication Sciences \& Disorders, 22(2), 272-283.

배효성(2004). 학령 초기 아동의 읽기 능력 별 읽기 오류 유형 분석. 서울대학교 대학원 석사학위논문.

심고우니, 정경희(2012). 초등학교 1-2학년 다문화가정 아동의 읽기유창성 특성. 언어치료연구, 21(2), 93-110.

오효진, 이윤경(2007). 초등 저학년 단순언어장애 아동의 읽기능력. 언어치료연구, 16(4), 61-74. 
우정한, 김상선(2010). 읽기장애학생의 언어능력과 읽기능력에 관한 연구. 특수교육저널: 이론과 실천, 11(3), 163-183.

우정한, 김상선(2012). 읽기장애학생의 읽기 특성 연구: 읽기장애의 유형, 읽기오류 유형 및 글 이해력 분석. 특수교육재활과학연구, 51(3), 197-218.

윤혜련(2005) '다시말하기'를 통해 본 학령기 단순언어장애아동의 이야기 이해 및 산출 특성. 이화여자대학교 대학원 박사학위논문.

이윤경, 허현숙, 장승민(2015). 학령기 아동 언어검사(LCCS). 서울: 학지사.

이은정(2014). 초등 3학년 아동의 이야기 이해와작업기억능력의 관계. 충남대학교 대학원 석사학위논문.

이지영, 김화수(2012). 2, 3학년 주의력결핍 과잉행동장애 아동의 읽기유창성 특성. 언어치료연구, 21(4), 191-208.

정종성(2013). 초등학교 읽기 교과서의 텍스트 난이도 위계화 탐색. 학습장애연구, 10(1),31-50.

최영경, 정훈영(2014). ADHD아동과 일반아동 간의 읽기유창성 및 읽기 이해력 비교 연구. 정서.행동장애연구, 30(4), 133-152.

한효정, 김미배(2018). 초등 3-4학년 언어학습장애 아동의 형태소인식능력과 읽기유창성, 철자쓰기 간의 상관관계. Communication Science \& Dis-

order, 23(2) 347-359.

\section{ORCID}

채시화(https://orcid.org/0000-0002-8716-0730); 김미배(https://orcid.org/0000-0001-9781-2520) 